\title{
Breast Augmentation
}

Editor

BRADLEY P. BENGTSON

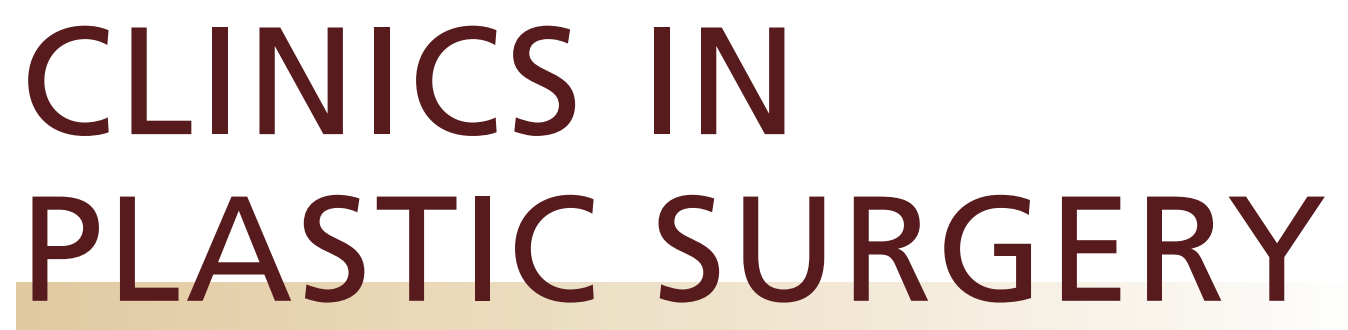

www.plasticsurgery.theclinics.com

October 2015 • Volume 42 • Number 4 